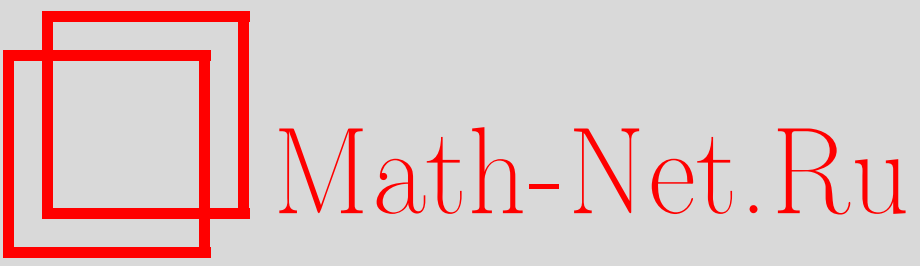

И. А. Александров, А. Ю. Васильев, М. М. Лаврентьев, А. В. Сычев, Василий Васильевич Черников (некролог), УМH, 1997, том 52, выпуск 6, 143-144

DOI: https://doi.org/10.4213/rm1601

Использование Общероссийского математического портала Math-Net.Ru подразумевает, что вы прочитали и согласны с пользовательским соглашением

http: //www. mathnet.ru/rus/agreement

Параметры загрузки:

IP : 18.207 .199 .55

26 апреля 2023 г., 13:02:52 


\section{ВАСИЛИЙ ВАСИЛЬЕВИЧ ЧЕРНИКОВ}

7 января 1997 года после тяжелой и продолжительной болезни скончался известный российский математик, специалист по теории функций комплексного переменного, доктор физико-математических наук, профессор Томского университета Василий Васильевич Черников.

В. В. Черников родился 16 июля 1930 года в городе Куйбышеве (бывшем Каинске) Новосибирской области. В 1949 году он поступил на механико-математический факультет Томского государственного университета.

В 1954 году после окончания с отличием ТГУ поступил в аспирантуру на кафедру математического анализа к профессору П.П. Куфареву. В 1962 году защитил кандидатскую диссертацию "Экстремальные задачи на некоторых классах аналитических функций с вещественными коэффициентами".

Вся трудовая деятельность Василия Васильевича прошла на кафедре общей математики Томского университета. С 1957 года он работал ассистентом кафедры, с 1961 - старшим преподавателем, с 1963 г. - доцентом кафедры.

В 1991 г. В. В. Черников защитил докторскую диссертацию "Геометрические свойства регулярных и мероморфных функций”. В феврале 1992 г. был избран профессором кафедры общей математики.

Опубликованные профессором В.В. Черниковым, в отдельных случаях совместно с коллегами и аспирантами, научные работы, охватьвающие широкий круг задач в проблематике современной теории функций, свидетельствуют о его интенсивной и плодотворной научной деятелности за 40-летний период (с 1957 по 1996 гг.). Им построен обобщенньй метод вариаций, представляющий собой сочетание вариационного метода Г.М. Голузина и метода площадей; выделены и получили решение новые задачи, связанные с обобщенной выпуклостью и обобщенной спиральностью однолистных функций; введены в рассмотрение новые функционалы, характеризующие уклонение линий уровня и их ортогональных траекторий и даны оценки этих функционалов; дано описание граничных функций некоторых систем функционалов на классе типично вещественных функций; решена проблема коэффициентов в классе типично вещественных функций.

Василий Васильевич любил преподавательскую работу, любил читать лекции, любил студентов. Глубиной познания читаемых курсов, особым даром увлечь слушателей, ясностью и доступностью изложения сложных тем он завоевал репутацию блестящего лектора.

Осуществлял руководство курсовых, дипломных работ на ММФ, выпускных работ слушателей ФПК при ТГУ. В период с 1969 по 1982 гг. руководил городским научным семинаром по ТФПК им. П. П. Куфарева. Василий Васильевич редактировал труды ТГУ "Вопросы геомет- 
рической теории функций" (вып. 7, 8, совместно с профессором И. А. Александровьм) и первые шесть выпусков "Экстремальные задачи теории функций”.

Интересы Василия Васильевича не ограничивались одной математикой. Он любил поэзию, ценил юмор, радовал коллег своим пением. Василий Васильевич был преданным мужем и отцом, нежно любившим своих детей и внуков.

Светлая память о Василии Васильевиче Черникове навсегда останется в сердцах всех соприкасавшихся с ним в жизни и работе.

И.А. Александров, А.Ю. Васильев, М. М. Лаврентьев, А. В. Съчев 